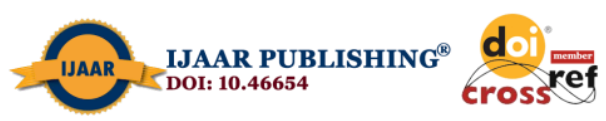

International Journal of Advanced Academic Research (Social and Management Sciences) | ISSN: 2488-9849 Vol. 6, Issue 6 (June, 2020) | www.ijaar.org

Journal DOI: 10.46654/ij.24889849

Article DOI: 10.46654/ij.24889849.s6615

\title{
SPECIALIZED INSTITUTIONAL FINANCING AND THE EFFICIENCY OF SMALL AND MEDIUM SCALE ENTERPRISES IN NIGERIA
}

\author{
J. I. Onyema \& Ijomah, N.C. \\ Department of Economics, \\ Faculty of Social Sciences, \\ Rivers State University, Nigeria.
}

\begin{abstract}
This paper examined the relationship between lending by specialized banks and the efficiency of small and medium scale enterprises in Nigeria between the periods 1992 to 2017. The model used Micro Finance Banks, African Development Bank, Bank of Agriculture and Bank of Industry loans as the independent variables with small and medium scale output serving as the dependent variable and also proxied their efficiency. The study used descriptive statistics, short-run static multiple regression, Phillips-Perron unit root test, Johansen cointegration and error correction estimates for pre and post estimation tests. The error correction estimates result show that Bank of Agricultural loan is negatively signed and does not significantly improve efficiency of small and medium scale enterprises while Micro Finance Bank, African Development Bank and Bank of Industry loan relate positively and significantly so with efficiency of small and medium scale enterprises in Nigeria. The study therefore recommends that in order for these financial institutions to keep up with high loan demand from entrepreneurs and small and medium scale enterprises, there is need for them to source for more funds from both internal and external sources. There is also the need for the government to support the activities of small and medium scale enterprises by granting soft loans to them through these specialized institutions.
\end{abstract}

Keywords: Financial Institutions Lending, Performance of Small and Medium Enterprise. 


\section{INTRODUCTION}

The financial sector consists of the financial market, institutions and instruments which help in making financial services available from surplus unit to deficit unit of the economy.

Availability of liquidity and its accessibility serve as an indicator of the development of the financial sector. To corroborate this assertion, Goldsmith (1969) and Shaw (1973) discovered that the financial sector responds to the financial needs of the economy which ultimately leads to the growth of both the financial sector and the economy in general. They also saw small and medium scale enterprises (SMEs) as the major stimulator of economic growth both in developing and developed countries going by the contributions of SMEs to overall national income. According to the Statistical Bulletin of the Central Bank of Nigeria, 2013, it can be seen that SMEs contributed $47 \%$ to gross domestic product (GDP). Well-functioning financial institution reduces poverty, unemployment and improves productivity in the country by extending loans to SMEs. Vytautas and Vitalija (2011) observed that economic growth has been engineered by the contribution of SMEs. Sanusi (2003) is of the view that over $96 \%$ of large manufacturing and construction firms originated from SMEs. Hallberg (2000) opined that they contribute to government revenue, reduction of unemployment and also a mechanism that propels growth in developing countries. Their contribution to increase in the standards of living and innovation necessitates the involvement of government and other corporate bodies in different fields to surmount the financial problem usually encountered by SMEs. Entrepreneurs are risk averse but they are also great thinkers. SMEs are run by entrepreneurs who can be seen as heterogeneous (diverse) cluster of vibrant innovative and elegant people who are willing to attain independence and take appropriate risk for their actions which is believed that it will command a reasonable return in value. The innovative ideas of these entrepreneurs are protected by property rights because their activity contributes immensely to the wealth of their country. Schumpeter (1934) in his famous theory evidences that entrepreneurs are major drivers of economic growth in developing country.

In the early 1960s, agriculture was majorly the activity that SMEs engaged themselves in which mainly involved all farmer corporative groups and society which was then categorized as SMEs, contributing tremendously to the nation's growth. This declined after the discovery of oil in Nigeria. People that engaged in such activity faced a series of environmental and financial difficulties. This propelled the federal government to introduce several schemes and credit institutions that helped to enhance productivity in agricultural output. Several schemes were initiated in order to empower entrepreneurs which were Commercial Bill Financing Scheme (1962), Nigeria Agricultural Corporative and Rural Development Bank (1972), Regional Commodity Board (1977), Sectoral Allocation of Credit and Condescension Interest, and Rural Banking Programme (1977). Early 1971 also witnessed the introduction of different schemes that were initiated by the military government in order to provide technical and financial support to SMEs namely; Small Scale Industries Credit Scheme (SSICS), which metamorphosed into Small Industries Credit Fund (SICF). This scheme made fund available on a generous and less strenuous terms to SMEs between 1975-1980. This scheme collapsed 
due to inexperienced expertise/technical team in extending sound loan facilities. 1973 witnessed the commencement of another bank which is Nigerian Bank for Commerce and Industry (NBCI) which specialized in extending loan facility to the grassroots. This bank financed close to 126 projects which were monitored under the World Bank loan scheme. They were accosted with the issue of insolvency in the early 80's which led to the establishment of the Bank of Industry (BOI). Agricultural Credit Guarantee Scheme Fund (ACGF) was introduced as far back as early 1977 and was placed directly under the supervision of the Central Bank of Nigeria. This scheme extended close to $75 \%$ loans to farmers and later metamorphosed into the Agriculture Credit Support Scheme which brought in the active participation of bankers committee. They helped in extending loan facilities to Agro-Allied entrepreneurs and farmers on a single digit basis of $8 \%$. In collaboration with water resources and federal ministry of agriculture, Commercial agriculture credit Scheme was introduced in 2009 and extended loans at 9\% maximum rate. Another scheme that extended loan for a period 15 years is the Small and Medium Enterprise Credit Guarantee Scheme (SMECGS) managed by bank of industry (BOI). It made it mandatory for all deposit money banks and development financial banks to participate in the scheme. This scheme basically focused on manufacturing and agricultural produce. In its 246th meeting held by banker's committee, approval was granted for the establishment of Small and Medium Enterprises equity investment Scheme (SMEEIS) in line with the collaborative effort of government in propelling rapid growth and industrialization. The scheme stipulated that all banks need to save $10 \%$ of their after tax profit (ATP) for investment in the activities of SMEs.

Due to the failure of the schemes introduced by the government, 2005 witnessed the introduction of microfinance institutions (MFIs), Agriculture National Poverty Eradication Programme (NAPEP), Trade Intervention Fund etc which were among a few that were initiated by the government, resulting to development of financial institution that caters for SMEs in Nigeria.

In Lithuania, Vytautas and Vitalija (2011)discovered that the introduction of venture capital as a source a financing by European Union was a very good idea because it increased investment in small businesses and actively got the government involved leading to a boost in output in the region.

SMEs are faced with the problem of inadequate capital and asset for takeoff and the capacity to easily repay loans, thus limiting banks from actively being involved in any of their financial needs (Oni and Ormin, 2012). Bharti and Shylendra, (2011) posits that expanding existing businesses is a great challenge that entrepreneurs face.

It is for the above reason that the federal government created a scheme that will alleviate the burden of SMEs that are willing to source loan from banks known as the Industries Equity Investment Scheme (SMIES). Other accessible sources of financing provided by government and international bodies to SMEs include, National Economic Reconstruction Fund (NERFUND), World Bank SMEs loan scheme, Bank of Industry 
(BOI), Graduate Employment Loan Scheme (GELS), African Development Bank Export Stimulation Loan (ADB/ESL) scheme, Re-discounting and refinancing facility. Alphonso and Olawale (2012) noted that ethical conduct can "compel" a financial establishment to grant credit facility to entrepreneurs in the absence of guarantee. The complexities attached to small and medium scale borrowing from the organized financial institution push entrepreneurs to prefer to shift to an alternative non-bank financial institution. SMEs are faced with tight liquidity which is a major constraint to them (Ogujiuba, Ohuche and Adenuga, 2014). Lack of funding kills original ideas that are generated by entrepreneurs. Taiwo et al, 2016 discovered that in five years, less than one percent of small businesses survive because of competition. Moreover, banks lending to SMEs is considered a charitable deed rendering such lending riskier compared to other investment outlets they can engage. Olutunla and Obamuyi, (2008) is of the view that SMEs have not performed well overtime in Nigeria to enable them attract the needed funds from conventional deposit money banks, because as observsed by Ogujiuba, Ohuche and Adenuga (2014) banks, being risk-averse, find it reluctant in their lending decisions to lend to SMEs. This therefore necessitates this investigation which focuses on the relationship between specialized financial institutions lending and the performance of small and medium scale enterprises (SMEs) in Nigeria.

\section{Conceptual Framework}

\section{Development Finance Institution (DFI)}

Financial institution represents an organization or establishment that helps in financial intermediation process within a geographical location and they include bank and non-bank financial institutions. They also accept deposits and extend loan facilities to deficit spenders, keep various accounts that suit their customers' tastes (savings, current, and fixed deposit) and can also be categorized as organized and un-organized financial institutions. Development finance institution (DFI) is a universal term that is used to define variety of institutions that render financial services, which include bank of agriculture, micro-finance bank, African development bank and bank of industry.

Adesoye and Atanda (2012) defined DFI as a financial institution that assists the government in extending loan facilities to subsectors of the Nigerian economy. These institutions adopt the project approach and the collateral approach in discharging their duties; provide loan, guarantee capital and other managerial functions to assist the deficit spending units. Default is mitigated because of the skilled resourceful, financial and technical managers they have at their disposal. DFIs are also noted with the speed and efficiency at which they implement their activities with little or no monitoring. 


\section{Small and Medium Scale Enterprise (SMEs) .}

What constitute SMEs differ from country to country and the level of economic development of the country, meaning that there is no one universally accepted definition of small and medium enterprises.

For instance, according to World Bank Group, Russia adopts different criteria for deferent industries in defining small and medium enterprises which are peculiar to it.

In defining small and medium enterprises, there are commonly used criteria adopted by many economies, which are based on number of employment, total assets, volume of sales, loan size and investment level. Efforts have been made over the years to simplify and agree on what should be the universally acceptable definition of a small and medium enterprise but have been difficult because of differences in economic development of various countries.

According to World Bank (2011) survey on the definition of small and medium enterprises from sixty eight countries, information obtained from financial regulators shows that fifty of them use number of employees, which is adjudged the bench mark definition and twenty nine out the number fifty also use loan size and sales criteria. A total of forty-nine regulators use maximum sales value criteria.

Oreoluwa, A.R. (2011) (cited in Onyema, J.I. \& Nwobike, G.A.D, 2019) identified three main parameters to be common among all countries as capital investment, volume of production and business turnover. Oreoluwa, A.R. (2011) defined small and medium enterprises in relation to employment generation.

The main indicator to define small and medium enterprises is the number of employees, which of course depends on the country's level of development. In other words, there is no universal number of employments that is agreed on. In Nigeria, enterprises with employee size of between 10 and 49 or asset base that ranges between $\mathrm{N} 5 \mathrm{~m}$ and $\mathrm{N} 49 \mathrm{~m}$ are regarded as small enterprises while firms with 50 employees but exceeding 149 or asset base of between $\mathrm{N} 50 \mathrm{~m}$ and N499m are grouped under medium enterprises (Onuoha, 2016 in Onyema, J.I. \& Nwobike, G.A.D, 2019 ), whereas in United Kingdom, firms with employee size from zero to forty nine are taken as small scale enterprises while fifty to two hundred and forty nine employees size constitute medium scale enterprises (UK Department of trade and industry, 2018).

For Asian countries, each country sets its own threshold that distinguishes retail service industries, wholesale trade, small and medium enterprises from the large scale. The essence of this threshold is to show the aggregate importance between an SME and a large enterprise in terms of importance. The other indicators used along with the number of employees are assets and sales turnover. However, not all the economies use the three criteria. A good number of the countries in Asia set two criteria, viz; number of employees and value of assets. 
In harmonizing the various countries' definitions of small and medium enterprises in European Union countries, the European commission defined small and medium enterprises based on the following criteria: number of employees, annual turnover and balance sheet size. The inclusion of annual turnover made the definition perfect. This is because sales turnover is a good measure of SMEs contribution to economic development and growth of a country. Despite the agreed definition of the SMEs by member nations, individual countries still have their own parameters and threshold set for the classification of this sector.

According to European Union, a firm with 250 employees, a turnover of 50 and balance sheet of 43 is a medium enterprise while a firm with 50 employees and 10 turnover and balance sheet size respectively fits into a small scale enterprise (Hidayet, Canan and Hakan, 2010 Onyema, J.I. \& Nwobike, G.A.D, 2019).

Small-scale industry in Japan is defined according to type of industry, paid-up capital and number of paid employees.

In Asian countries, within the same country, industries, ministries, and other organizations adopt different criteria in the definition of small and medium enterprises. As if this is not enough, different sectors use different criteria also.

There are contending opinions from researchers, small and medium enterprises promoters, government and policy makers that those countries that adopt three criteria namely employees, asset base and sales turnover are the most accurate parameters that help the financial institutions in taking decision for financial assessment, However, in evaluating eligibility of financial assistance by banks, asset and sales turnover are the important parameters needed in taking decision. In granting of loan, financial institutions do not take into account number of employees a prospective customer has when reviewing loan request, rather it places much premium on sales turnover and assets quality of the company.

Pfaffer (1968) use the following criterion in defining what constitutes small and medium enterprises,

$>$ Retail or service - annual sales or receipts not more than one million dollars $(\$ 1 \mathrm{~m})$.

$>$ Wholesale or service - annual or receipts of not more than five million $(\$ 5 \mathrm{~m})$.

$>$ Manufacturing - small if it has not more than 259 employees

In the above definition, the author was silent on the number of paid employees. Essien (2001) listed some developed and developing countries' definitions of small and medium enterprises. UNIDO uses different figures but same parameters for developing and developed countries. For developed countries, UNIDO uses employee strength of 1 to 99 to define small enterprises and employee size of between 100 to 500 to describe medium scale enterprises while for developing countries, a medium scale enterprise is one with employee size of between 20 and 99 and a small scale enterprise is one with employee size of 5 to 19 people (Onuoha, 2016 Onyema, J.I. \& Nwobike, G.A.D, 2019). 


\section{THEORETICAL FRAMEWORK}

\section{Financial Intermediation Theory}

This theory highlights two categories of people, those that save and those that spend, this is an aspect that deals with extending loan facility to the deficit spending economic unit that is in short of finance. This facility is propelled by the surplus economic unit. Financial intermediation is therefore the process by which surplus economic unit decide to make sound and effective use of their surpluses income in order to acquire an additional income (return) by challenging it to sound productive investment ventures. There are several empirical facts that support this ideology, below are a few of the scholars that uncovered it in their previous work; Schumpeter (1934), Goldsmith (1969), McKinnon (1973) and Shaw (1973).

\section{Schumpeter Theory}

This talks about invention and innovation. Invention is discovery of new technology (new way of doing things) or technique while innovation is a practical application of invention to reality (concern). This theory postulates that financial institution is established for the purpose of funding new ideas and innovation which originate from entrepreneurs who have the ability to foresee new ideas. The idea behind this is that financial institutions play a lead role in supplying funds for innovators or inventors (entrepreneurs) in order to achieve their goals which is production in an economy. Schumpeter sees entrepreneur as the kingpin of any enterprise, taking him out of the economy, the economy cannot sour high in terms of production. The ability of this entrepreneur to have access to the funds by organized financial institution as at when due is very important and a major driver of development in the economy. An argument can spring forth that SMEs are a complement in the theory, placing more emphasis on financial institution than that of SMEs. Since the entrepreneurs are the ones that are given this facility, they fall into the category of SMEs. Then the basis of the argument might be irrelevant because they both complement each other since there cannot be a business concern without funds being dispensed to finance the idea that was conceived by the entrepreneur.

\section{Empirical Review}

Owenvbiugie and Igbinedion (2015) examined how funds propel growth in activity of SMEs. Making use of oral interview and questionnaire which was distributed to 122 persons who were randomly selected based on beliefs, behavior, attitudes and feelings. The study drew an inference that anything that serves as a barrier, mostly the stringent and inaccessible securities should be eradicated from the requirement that financial houses demand for accepting any loan application.

In Kuliyapitiya (Sri Lanka), Ranjith and Dayaratna-Banda (2014) investigated factors that determine the success of SMEs in the west and east of Kuliyapitiya. The study made use of 
contextual entrepreneurs, startup capital, and the skill they had acquired to take sound investment decision.

In Bangalore (India), Theamozhi and Amaladas (2014) studied how legal concerns (businesses) who employ less than 50 workers could improve their productivity. They attested to the fact that micro small and medium enterprises (SMEs) bridge the output gap by engaging in productive activity, thus, reducing unemployment and waste in the country. Thus, they engender competition which is healthy for businesses to thrive in terms of competition. In the quest to underscore the difficulties in financial inclusion in relation to the failure to meet security requirements, Oleka, Maduagwu and Igwenagu (2014) examined channels through which micro finance banks use in speeding up efficiency of SMEs, making use of both qualitative and quantitative data for a 10-year period, and a total number of 300 respondents were selected randomly. They discovered that access to these funds significantly enhance their productivity. Secondly, growth of sales has an unsubstantial connection with that of servicing of loan because the duration is short for any meaningful growth to be achieved.

Ogujiuba, Ohuche and Adenuga (2014) investigated how credit crunch affects SMEs, making use of cross sectional and theoretical underpinning to ascertain the dilemma the shortage of funds could cause to growing businesses. They discovered that credit crunch was as a result of volatility in the economic environment and lack of access to communal capital market. In order to reduce the effect of credit crunch, specialized financial institutions needed to undertake the activity of extending sound loan to SMEs by reducing the volume of collateral demanded from them taking into consideration their weak asset base.

In Bangladesh, the method of financing is attached to creditability and ability to factor various categories of deficit spenders into groups and making loan facility available to them. Whenever this loan was repaid to them, they would use it to foot the financial need of another group. In Brazil, the government helps in financing and extending loan facility to specific areas and encourages clustering of firms tailored towards a specific need making reference to (SINOS VALLEY) industries that produced shoes which helped in fostering growth. Due to the risky nature of MSMEs and the informality in setting them up, deposit taking institutions practically shied away from extending credit facility to MSMEs.

These worries propelled Awoyemi, Olayoriju and Kashira (2014) to investigate how this bottleneck and stringent conditions would be averted. They drew logical inference from previous studies and different views of scholars, which summed up to a logical inference. It was discovered that it is essential to involve third-tier market a subsector under the capital market in actively engaging in extending such facility to MSMEs. Moreover, the activity of MSMEs contributes over $70 \%$ to GDP, whereas they contribute to employment and improve the standard of living in the country by mitigating the rate of unemployment to the tune of 95\% employing people within the working-class age. 


\section{Model Specification}

\section{Functional Equation}

Below represents the model that is to be used to carry out our analysis, this shows the relationship between the intercept and the slope.

SMEQ $\quad=\quad \mathrm{f}(\mathrm{MFBL}, \mathrm{BOAL}, \mathrm{BOIL}, \mathrm{ADBL})-------------(1)$

\section{Mathematical Equation}

The functional equation can further be transformed to equation two below; here constant parameter $(\beta)$ is introduced:

$\mathrm{SMEQ}={ }_{\beta_{0}}+{ }_{\beta 1} \mathrm{MABL}+{ }_{\beta 2} \mathrm{BOAL}+{ }_{\beta 3} \mathrm{BOIL}+{ }_{\beta 4} \mathrm{ADBL}$

\section{Econometrics Equation}

For econometric purpose the error term is added to equation 3 which can be rewritten as:

$\mathrm{SMEQ}={ }_{\beta 0}+{ }_{\beta 1} \mathrm{MABL}+{ }_{\beta 2} \mathrm{BOAL}+{ }_{\beta 3} \mathrm{BOIL}+{ }_{\beta 4} \mathrm{ADBL}+\mu_{\mathrm{t}}$

Where

A priori $={ }_{\beta 1}>0,{ }_{\beta 2}>0,{ }_{\beta 3}>0,{ }_{\beta 4}>0,{ }_{\beta 5}>0$.

SMEQ $\quad=\quad$ Small and Medium Scale Output

MFBL = Micro finance bank loan

BOAL $\quad$ Bank of agriculture loan

BOIL $=$ Bank of industry loan

$\mathrm{ADBL} \quad=\quad$ African development bank loan

$\beta 1, \beta 2, \beta 3, \beta 4=$ Estimation parameters

$\beta 0=$ Constant Parameter

\section{Analysis of Data}

Descriptive Statistics

In order to ascertain the movement of the data, descriptive statistics will be used for this purpose. 
Table 1 Descriptive Statistics

\begin{tabular}{|c|c|c|c|c|c|}
\hline & SMEQ & MFBL & BOAL & BOIL & ADBL \\
\hline Mean & 24261.60 & 35619.20 & 3937778. & 1507.506 & 996.5856 \\
\hline Median & 13017.17 & 11353.80 & 2083745. & 1032.700 & 527.5800 \\
\hline Maximum & 75598.92 & 169735.3 & 10029489 & 3742.170 & 4876.500 \\
\hline Minimum & 582.2079 & 135.8000 & 81273.80 & 53.03000 & 337.2900 \\
\hline Std. Dev. & 25204.97 & 47410.30 & 3869859. & 1380.458 & 1288.679 \\
\hline Skevvness & 0.846291 & 1.528141 & 0.318760 & 0.526364 & 2.324034 \\
\hline Kurtosis & 2.336312 & 4.525231 & 1.366455 & 1.681235 & 6.711025 \\
\hline Jarque-Bera & 3.443034 & 12.15332 & 3.203024 & 2.966020 & 36.85025 \\
\hline Probability & 0.178795 & 0.002296 & 0.201592 & 0.226953 & 0.000000 \\
\hline Sum & 606539.9 & 890480.1 & 98444453 & 37687.65 & 24914.64 \\
\hline SumSq. Dev. & $1.52 \mathrm{E}+10$ & $5.39 \mathrm{E}+10$ & $3.59 \mathrm{E}+14$ & 45735969 & 39856661 \\
\hline Observation & 25 & 25 & 25 & 25 & 25 \\
\hline
\end{tabular}

\section{Source: Output result from E-views 10}

The data behavior is presented above in the descriptive statistics, where BOAL has the highest mean value of 3937778, which is followed by MFBL's value of 35619.20 followed by that of SMEQ of 24261.60. BOIL has a mean value of 1507.506 while ADBL has the least mean value of 996.5856. The highest median noted in BOAL 2083745, followed decreasingly by SMEQ (13017.17), MFBL (11353.80), BOLT (1032.700) and ADBL (527.5800). Standard deviation is used to measure how volatile the variable is, BOAL (3869859) is the most volatile variable, followed by MFBL (47410.30), then SMEQ (25204.97) and BOIL (1380.458) and finally ADBL (1288.679). Three variables are platykurtic in nature. BOAL (1.366455), BOIL (1.681235) and SMEQ (2.336312) are platykurtic because they have less than 3 indicating a thin tail compared to the standard normal distribution, which indicates that they tend to have less major fluctuation than the rest. While MFBL (4.525231) and ADBL (6.711025) are leptokurtic in nature, because the kurtosis value is larger than 3 .

This test is used to ascertain the order of stationarity in the trend.

Table 2: $\quad$ Phillips-Perron test Unit Root Test

\begin{tabular}{lllllll}
\hline Variables & PP & $\begin{array}{l}\mathbf{1 \%} \\
\text { critical } \\
\text { level }\end{array}$ & $\begin{array}{l}\mathbf{5 \%} \\
\text { critical } \\
\text { level }\end{array}$ & $\begin{array}{l}\mathbf{1 0 \%} \\
\text { critical } \\
\text { Level }\end{array}$ & Prob* & Order of \\
\hline D(SMEQ) & -5.582831 & -4.39431 & -3.6122 & -3.24308 & 0.0007 & Integration \\
D(MFBL) & -7.280013 & -4.39431 & -3.6122 & -3.24308 & 0.0000 & $1(1)^{*}$ \\
D(BOAL) & -13.0059 & -4.39431 & -3.6122 & -3.24308 & 0.0000 & $1(1)^{*}$ \\
D(BOIL) & -5.94173 & -4.39431 & -3.6122 & -3.24308 & 0.0003 & $1(1)^{*}$ \\
D(ADBL) & -8.48493 & -4.39431 & -3.6122 & -3.24308 & 0.0000 & $1(1)^{*}$ \\
\hline
\end{tabular}


Table 2 shows that the variables are stationary at first difference. Subsequently, the critical value at $5 \%$ level is less than the computed value, making us to accept stationarity at order one 1(1). This is a pre-requisite for Johansen co-integration test since all the variables are integrated at order one. Before then we need to establish if relationship can be seen in the short run between the variable holding one constant.

Table 3: Johansen Co-Integration Test

\begin{tabular}{cllll}
\hline Hypothesized & & Trace & 0.05 & Critical \\
No. of CE(s) & Eigenvalue & Statistic & Value & Prob.** \\
\hline None $*$ & 0.955787 & 169.9550 & 69.81889 & 0.0000 \\
At most 1 $*$ & 0.919992 & 98.22394 & 47.85613 & 0.0000 \\
At most 2 $*$ & 0.717217 & 40.13458 & 29.79707 & 0.0023 \\
At most 3 & 0.308177 & 11.08388 & 15.49471 & 0.2064 \\
At most 4 & 0.107280 & 2.610100 & 3.841466 & 0.1062
\end{tabular}

\section{Source: Output result from E-views}

Trace test indicates 3 cointegrating equations at the 0.05 level.

*Denotes rejection of the hypothesis at the 0.05 level

From the result above, since the trace statistics is higher than the critical value at $5 \%$ level in three different hypothesized situations then we can conclude that there is long run equilibrium among the variables. We can also suggest that there are three co-integrating equations in the model, meaning that the variables have mutual stochastic trend and there is a long run association between the variables under investigation. The first three hypothesized equations show that there is a significant association noticeable using the probability value which is seen to be less than the critical confidence level. This result further necessitates the error correction model (ECM).

This analysis shows the relationship that exists between each of the variables under investigation. 
Table 4: Multiple Regression Analysis

\begin{tabular}{lllll}
\hline Variable & Coefficient & Std. Error & t Statistic & Prob. \\
\hline C & -1608.651 & 719.5227 & 2.235720 & 0.0369 \\
MFBL & 0.105369 & 0.028350 & 3.716731 & 0.0014 \\
BOAL & -4.010006 & 0.000261 & 0.015385 & 0.9879 \\
BOIL & 12.25080 & 1.058773 & 11.57075 & 0.0000 \\
ADBL & 3.677298 & 0.633967 & 5.800456 & 0.0000 \\
\hline R-squared & 0.993959 & Mean dependent var & 24261.60 \\
Adjusted Rsquared & 0.992751 & S.D. dependent var & 25204.97 \\
S.E. of regression & 2145.938 & Akaike info criterion & 18.35740 \\
Sum squared resid & 92101031 & Schwarz criterion & 18.60117 \\
Log likelihood & -224.4675 & Hannan Quimi criter. & 18.42501 \\
F-statistic & 822.7306 & Durbin-Watscm slat & 1.675605 \\
Prob(F-statistic) & 0.000000 & & \\
\hline
\end{tabular}

\section{Source: Output result from E-views}

Decision Criterion: Whenever the probability value is greater $(>)$ than $0.05 \%$ critical value, then we reject the alternative hypothesis $\left(\mathrm{H}_{\mathrm{A}}\right)$.

\section{Test of Hypotheses}

Following the report above, microfinance banks loan exhibits a positive coefficient of 0.105369 alongside a significant P-value of 0.0014 which is less than 0.05 level of significance, thus suggesting acceptance of the alternate hypothesis, which states that micro finance Bank loan significantly promotes small and medium scale output in Nigeria. The second result shows that bank of agriculture loan shows a negative coefficient of -4.010006 with P-value of 0.9879 which is greater than 0.05 level of significance, thus suggesting acceptance of the null hypothesis, which states that bank of agriculture loan does not significantly promote small and medium scale output in Nigeria. This is followed by bank of industry loan with a positive coefficient of -12.25080 with a P-value of 0.0000 (which is less than 0.05 level of significance) thus suggesting the acceptance of the null hypothesis that bank of industry loan significantly promotes small and medium scale output in Nigeria. Finally, African development bank loan has a positive coefficient of 3.677298 and a significant relationship (P-value of 0.0000) with small and medium scale output. This propels us to accept the alternate hypothesis $\left(\mathrm{H}_{\mathrm{A}}\right)$ which can be concluded that African development bank loan significantly promotes small and medium scale output in Nigeria.

\section{Presentation of Error Correction Test Result}

This model corrects the distortion between the long run and the short run. 
Table 5: The output of the Error Correction Model (ECM)

\begin{tabular}{lllll}
\hline Variable & Coefficient & Std. Error & t-Statistic & Prob. \\
\hline & & & & \\
C & -1565.344 & 788.7107 & -1.984687 & 0.0626 \\
MFBL & 0.108888 & 0030002 & 3.629311 & 0.0019 \\
BOAL & 3.260005 & 0.000276 & 0.118102 & 0.9073 \\
BOIL & 12.12066 & 1.126886 & 10.75589 & 0.0000 \\
ADBL & 3.540290 & 0.686069 & 5.160254 & 0.0001 \\
ECM(-l) & -0.098942 & 0.237274 & -2.416818 & 0.0305 \\
\hline
\end{tabular}

\begin{tabular}{|c|c|c|c|}
\hline R-squared & 0.993899 & Mean dependent var & 25248.24 \\
\hline $\begin{array}{l}\text { Adjusted } \\
\text { squared }\end{array}$ & R- 0.992204 & S.D. dependent var & 25249.10 \\
\hline S.E. of regression & 2229.308 & Akaike info criterion & 18.46909 \\
\hline Sum squared resid & d 89456687 & Schwarz criterion & 18.76360 \\
\hline Log likelihood & -215.6291 & $\begin{array}{l}\text { Hannan-Quinn } \\
\text { criter. }\end{array}$ & 18.54722 \\
\hline statistic & 586.4778 & Durbin-Watson stat & 1.981629 \\
\hline rob(F-statistic) & 0.000000 & & \\
\hline
\end{tabular}

\section{Source: Output result from E-views}

The global statistics indicates that ECM which measures speed of adjustment in the long run is seen to be $-0.09 \%$, while the co-efficient of determination is $99 \%$ implying that the variables are quite suitable in explaining changes in small and medium enterprises output.

\section{The Relative Statistics Results}

On the long run similar trend is applicable to the error correction model as we accept the alternate hypothesis between MFBL and SMEQ since the probability value (less than 5\%) falls within the acceptable range of $0.05 \%$. This is followed by the coefficient of BOAL which stands at 3.260005. It is contrary to the result obtained in the short run (-4.010006) in Table 4. We conclude that while BOAL does not promote output of small and medium scale enterprises in the short run, it does in the long run. Bank of Industry loan (BOIL) is also seen to trend positively in both short and long run and significantly so. ADBL also followed the same positive trend in both runs. 
Table 6: Pairwise Granger Causality Tests

\begin{tabular}{lccc}
\hline Null Hypothesis: & Obs & F- & Prob. \\
& & Statistic & \\
MFBL does not Granger Cause SMEQ & 23 & 8.76380 & 0.0022 \\
SMEQ does not Granger Cause MFBL & & 6.34561 & 0.0082 \\
BOAL does not Granger Cause SMEQ & 24 & 3.60942 & 0.0469 \\
SMEQ does not Granger Cause BOAL & & 0.72002 & 0.4996 \\
BOIL does not Granger Cause SMEQ & 24 & 11.7759 & 0.0005 \\
SMEQ does not Granger Cause BOIL & & 0.16148 & 0.8520 \\
ADBL does not Granger Cause SMEQ & 24 & 19.0239 & 0.0005 \\
SMEQ does not Granger Cause ADBL & & 6.32565 & 0.0078 \\
BOAL does not Granger Cause MFBL & 23 & 1.07931 & 0.3608 \\
MFBL does not Granger Cause BOAL & & 0.86008 & 0.4398 \\
BOIL does not Granger Cause MFBL & 23 & 2.79960 & 0.0874 \\
MFBL does not Granger Cause BOIL & & 0.34197 & 0.7149 \\
ADBL does not Granger Cause MFBL & 23 & 9.81794 & 0.0013 \\
MFBL does not Granger Cause ADBL & & 6.94073 & 0.0058 \\
BOIL does not Granger Cause BOAL & 24 & 2.85283 & 0.0825 \\
BOAL does not Granger Cause BOIL & & 1.35156 & 0.2826 \\
ADBL does not Granger Cause BOAL & 24 & 0.09949 & 0.9058 \\
BOAL does not Granger Cause ADBL & & 2.21130 & 0.1370 \\
ADBL does not Granger Cause BOIL & 24 & 0.68736 & 0.5150 \\
BOIL does not Granger Cause ADBL & & 3.41613 & 0.0540 \\
\hline Source Output result from & & &
\end{tabular}

\section{Source: Output result from E-views}

\section{Analysis of the Result}

Bi-directional causality can be seen between MFBL and SMEQ. This means they both can influence each other. The same is true between ADBL and MFBL and between ADBL and SMEQ.

\section{Interpretation of Findings}

Table 4 shows that micro finance bank loan (MFBL) has a positive co-efficient of 0.105369 and significant relationship (p-value of 0.0014) with SMEQ in that for every one naira increase in MFBL there will be about 0.105369 units increase in SMEQ. This confirms our a priori expectation. The p-value agrees with our alternate hypothesis of the existence of a significant relationship between MFBL and SMEQ. It also indicates that the duration of the microfinance loans and advances to SMEs is enough for any meaningful production to effectively take place, in line with Oleka, Macluagwu and Igwenagu's (2014) findings. The result also agrees with the findings of Kasimu (2015) that discovered a significant number of the SMEs benefitted from the MFBLs loans even though only few of them were capable of securing the required amount needed. Bank of agriculture loan (BOAL) has a negative co- 
efficient of -4.010006 and non-significant relationship (p-value of 0.9879) with SME, implying that the null proposition can be accepted. This literally means that for every naira rise in MFBL there will be a reduction of about 4.01E units in the output of SMEQ which runs contrary to our second a priori expectation. This result supports Iloh and Chioke (2015), Osotimehin, Jegede, Akinlabi and Olajide (2012), the reduction and the negative relationship identified is as a result of difficulty in accessing banks of agriculture loan due to huge cost of borrowing and collateral requirement. Most SMEs operators patronize semi-formal financial institutions like (Micro finance and Co-operative Society) whose cost of loan is considerably and relatively low. Bank of industry loan (BOIL) supports the finding of the first model with a coefficient value of 12.25080, implying that for every one naira increase in BOIL output will increase by about 12.25080 units. We also accept the a priori sign as anticipated. With a P-Value of 0.0000 , the null hypothesis is also rejected. Looking at the values of the coefficients closely, it can be seen that BOIL has the highest contributing value in comparison to any other variable used to proxy financial institutions. This finding supports Usman, Ahmed and Yahaya (2015) and Ali, Jatai and Ashami (2016). This study discovered that bank of industry extends credit to the service and industrial sector which propels output. The positive relationship arises as a result of the 7\% interest rate which was charged on loans advanced to customers and a 15 years' loan tenor which makes provision for refinancing/restructuring facilities. Finally, African development bank loan (ADBL) has a positive co-efficient of 3.677298 and significant relationship (p-value of 0.0000) with SMEQ. The positive relationship is as a result of the various schemes that were introduced by these banks that helped to cushion the level of poverty rate, creation of employment opportunities, improving the standard of living (Folorunso, Abodunde and Kareem, 2015). Judging by this, our a priori sign is thus accepted meaning that an increase of about 3.677298 units of output will accrue to SMEQ as a result of increasing loans to them by one naira.

\section{Discussion of Findings}

Using of micro finance bank, African development bank, bank of agriculture and bank of industry loans as the independent/explanatory variables while efficiency of small and medium scale enterprises (SMEs) in Nigeria served as our dependent variable, the study found the following:

I. It was discovered that the data used in this study are normal distribution (Table 1).

II. The stationarity test was carried out with the help of Phillips-Perron (PP) unit root test and it was discovered that the variables are stationary at level one.

III. The multiple regression analysis revealed that only one variable which is bank of agricultural loan has a negative and non-significant relationship with small and medium scale output in Nigeria while the micro finance bank, African development bank and bank of industry loan have positive and significant relationship with small and medium scale output in Nigeria. 
IV. Johansen co-integration test revealed that there are three co integrating equations implying that there is long run equilibrium among the variables.

\section{Conclusion}

This study has established that there is a positive relationship between micro finance bank, African development bank and bank of industry loans while bank of agricultural loan has a negative relationship with efficiency of small and medium scale enterprises in Nigeria.

The loans from microfinance banks, African development bank and bank of industry make impressive and significant contributions in the output efficiency of small and medium scale enterprises in Nigeria.

The model, judging from the F-value is significant to be relied upon in making policies for the small and medium scale enterprises in Nigeria.

\section{Recommendations}

(1) Bank of agriculture should concentrate on the extension of loans to the agricultural sector. Besides, there is the need to monitor closely the deployment of agricultural loans to ensure that farmers do not divert them to other uses. This way, loans to agriculture will have a meaningful impact on agricultural produce, if not in the short run, then in the long run.

(2) Since the study has established a positive relationship between efficiency of small and medium scale enterprises and loans from bank of industry, micro finance banks and African development bank, it is important that more loans be extended to SMEs to enhance their contribution to the country's gross domestic product and continuous engagement of the labour force.

(3) Policies should be put in place to check the cumbersome collateral/security required from small and medium scale entrepreneurs by financial institution in the process of them securing loan facility. 


\section{References}

Abasilim, A.N (2015) Factors that affect the performance of women entrepreneurs in the micro scale enterprises, in southwestern Nigeria. The business \& management review, 6(2), 24-26

Abosede J.A Hassan A.B, \& Oko-Oza O. R (2017) performance of small and medium enterprises in Lagos State: The implications of finance. ACTA Universitatis Danubius. 5(13), 8-6.

Adesoye A. B \& Atanda A A. (2012) Development finance institutions in Nigeria: Structure, roles and assessment. Online at https://mpra.ub.unimuenchen.de/35839/MPRA Paper No. 35839,

Akhuernonkhan, I. A., Raimi, L., \& Sofoluwe, A. O. (2013). Entrepreneurship education and employment stimulation in Nigeria. Journal of studies in social sciences, 3(1), 5-6.

Akinola, A.O \& lordoo D.O (2013) Effects of the Nigerian capital market on the micro, small and medium scale enterprises (MSMEs) in Nigeria. Research Journal of finance and accounting. (4)7, 22-28.

Alese, O.J. (2017). Strategic management and the development of small and medium enterprises in south-west, Nigeria. An unpublished PhD Thesis of Olabisi Onabanjo University, Ogun state, Nigeria.

Ali J. I; Jatai S. \& Ashami P. I. (2016), Impact of deposit money banks' credit and investment drive of developing economies (Nigeria). Asian journal of agricultural extension, economics and sociology, 11(1), 1-12

Alphonso, V.A.S \& Olawale, O.F (2012), Debt financing to new small ventures in South Africa: The impact of collateral, ethics and the legal system. African Journal of business management. 6(3), 1136-1146, 25.

Awoyemi, B.O. Olayoriju, O.M and Kashim, I.T (2014). The challenges of financing micro, small and medium scale enterprises (MSMEs) in Nigeria.16275-290

Babafemi, D.I, Adesheye, M.I \& Akure Z (2015). Small and medium scale enterprises financing and development in Nigeria: A critical assessment journal of finance and bank management. (3), 190-198. .

Balogun, A.O, Nazem, A \& Agumba, J.A (2016), Determinants predicting credit accessibility within small and medium-sized enterprises in the south African construction industry. Procedia Engineering 164. !473 -480. 
Banji, O. O. (2010) SME: Issues, Challenges and Prospects; Presentation at FSS 2020 International Conference

Bharti, N. \& Shylendra H. (2011). Microfinance and sislainable micro entrepreneurship development, institute of rural management.

Chen, H. Miao, J. \& Wang, N. (2010) Entrepreneurial finance and non-diversifiable risk. Review of Financial Studies. 23(12),4348-4388. doi:10.1093/rfs/hhql22.

Chinaemerem, O. C. \& Anthony, O. (2012) Impact of capital structure on the financial performance of Nigerian firms; Arabian journal of business and management review OMAN Chapter), 1, (12),139-195.

Denis D.J. (2004). Entrepreneurial finance: An overview of the issues and evidence, journal of corporate finance. 10 (4)301-326. doi:10.1016/S0929-1199(03)00059-2.

Edelen, R. M. \& Kadlec, G. B. (2013) Investor base, cost of capital and financial performance: the case of post issuance anomalies; seminar presentation, Hong Kong university of science and technology.

Etnk, R.U, Etuk, G.R \& Baghebo, M. (2014). Small and medium scale enterprises (SMEs) and Nigeria's economic development. Mediterranean journal of social sciences. 5(7); 656-662.

Evbuomwan, G.O.; Ikpi, A.E; Okoruwai, V.O. \& Akinyosoye, V.O. (2013). Sources of finance for micro, small and medium enterprise in Nigeria 19" international farm management progress. Retrieved from www.ifmaonline.org

Folonmso, O.O., Abodunde, S.M., \& Kareem, T.S. (2015). Small and medium scale enterprises and economic growth and development in Nigeria: An empirical investigation. International journal in management and social science. 03(4), 23211784 .

Foluke, A. \& Olumide, A. (2004). Entrepreneurship development business ownership and women empowerment in Nigeria. Journal of business diversity, 12(1).

Frelinghaus, A. Mostert, B. \& Firer, C. (2005). Capital structure and the firm's life stage. South African journal of business management, 36(4), 9-18.

Goldsmith, R.W. (1969), Financial structure and development, New Haven, CT: Yale University Press 
Gubitta, P. \& Gianecchini, M. (2002). Governance and flexibility in family-owned SMES. Article in family business review, 15 (4) DOL10.1111/j. 1741-6248.2002.00277.

Hallberg K. (2000). A Market Oriented strategy for small and medium scale enterprises, international finance corporation discussion Paper, 40, April. Retrieved from www.siteresonrces.worldbank.org/intexpcomnet/hallberg_2000 .pdf

Ikechukwu, S.I \& Torbira, L.L (2016). Microcredit in the Nigeria's economic growth process: A multi sectorial analysis. Nigeria Journal of financial research 10(1). 1-12.

Iloh J. \& Chioke N. (2015). Commercial banks' credits indicators and availability of credit facility to small and medium scale enterprises in Nigeria. International conference on business, law and corporate social responsibility (ICBLCSR'15). Retrieved from Bali (Indonesia) http://dx.doi.org/10.15242/ICEHM.ED0515051 100.

Kasimu, S.Y. (2015). "The functions and operations of development in Nigeria micro financing", International journal of economics, 4 (10), 222-248

Kayode, E.B. \& Afred, O.I. (2014). Determinants of factors influencing capacity of small and medium enterprises in employment creation in Lagos State, Nigeria. International Journal of Financial Research, 5(2), 138-140

Khaled, A. M. A. \& Samer, F. O. (2013) Impact of cost of capital, financial leverage and the growth rate of dividend on return on investment. An empirical study of Amman stock exchange; International journal of academic research in economics and management sciences,2(4), 59-69.

Lavoie, D. (2005). A new era for female entrepreneurship in the 80's. Journal of small business (Canada), winter.

Mckinnon R (1973): Money and capital in economic development. Washington d.c: the bookings institution.

Metu, A, Nwokoye, E. S. \& Kalu, C (2015). Investigating impediments to accessing finance by female micro entrepreneurs in Awka, Nigeria. 15 metu conference.

Modigliani, F. \& Miller, M. H. (1963). Corporate income taxes and the cost of capital: A correction. American economic review, 53 (3),433-444. 
Mohammed, I \& AH, I (2015). The effect of smes' cost of capital on their financial performance in Nigeria. Journal of finance and accounting, 3(1),811.DOI:1012691/jfa-3-1-2/

Musa, G.G. \& Aisha, U. (2012).Financial small and medium scale enterprises (SMEs): A challenge for entrepreneurial development in Gombe State, Asian journal of business and management sciences. 2 (9), 17-23.

Myers, S. (1984), The Capital structure puzzle, Journal of Finance, 3(34),575-592.

Ngo, C. N., \& Chi, M. (2017). Differentials in market constraints and value addition among micro, small, and medium enterprises in Viet Nam (No. 082). World institute for development economic research (UNU-WIDER).

Nwakanma, P C., Nnamdi, 1 S \& Omojefe, G.O (2014). Bank credits to the private sector: potency and relevance in Nigeria's economic growth process. Accounting and finance research. 3(2).

Oboro, O. G. \& Ighoroje, E. J. (2011). Financing small scale business enterprises in Nigeria: a review of the problems and the way forvjard.lnternational journal of economic development research and investment. 2.(3)4-5.

Odah, O. (2005). The impact of federal government reform program on the development of the SMEs sector. National seminar on facilitating easy access to the SMIEIS finds by SME operators Lagos.

Odeyemi, J. A. (2003). An Overview of the current state of SMES in Nigeria and the need for intervention. A Paper Presented at the National Summit on SMIEIS organized by the bankers' committee and Lagos chambers of commerce and industry (LCCI), Lagos, 10th June

Oduyoye, 0.0. Adebola, A.S \& Binuyo, O.A (2013). Services of small and medium enterprises development agency of Nigeria (SMEDAN) and small business survival in Ogun State, Nigeria. Singaporean Journal of business economics, and management studies. 1(1),11.

OECD, 2005, OECD SME and Entrepreneurship Outlook: 2005, OECD Paris, page 17

Ogujiuba, K. K, Ohuche, F. FL \& Adenuga, A. O. (2014). Credit Availability to Small and Medium Scale Enterprises in Nigeria: Importance of New Capital Base for Banks Background and Issues. Working Paper. 
Olaniyan, D. A., \& Okemakinde, T. (2008). Human capital theory: Implications for educational development. Pakistan journal of social sciences, 5(5), 479-483. I

Olanrewaju, A. B, Ansary, N. \& Justus, N. A. (2016). Determinants predicting credit accessibility within small and medium-sized enterprises in the South African construction industry. Procedia Engineering, 164. 473-480

Oleka, C.D. Maduagwu, E.N \& Igwenagu, C.M (2014). Analysis of the impact of microfinance banks on the performance of small and medium scale enterprises in Nigeria. International Journal of science and allied research. 1(2),45-63.

Olutunla, G.T. \& Obamuyi, T.M. (2008). An empirical analysis of factors associated with the profitability of small and medium - enterprises in Nigeria. African journal of business management. (2) 195-200.

Oni, K. Paiko, I. \& Ormin, O. (2012) Assessment of the contribution of micro finance institutions (MFIs) to sustainable growth of small and medium scale enterprises (SMEs) in Nigeria. Interdisciplinary Journal of contemporary research in business.3, 9.

Oni, O \& Daniya, A. A. (2012) Development of small and medium scale enterprises: the role of government and other financial institutions. Arabian journal of business and management review (OMAN Chapter) 1(7),

Onyema, J.I. \& Nwobike, G.A.D.(2019). Bank Credit \& Performance of Small \& Medium Enterprises in Nigeria. CORE Journal of Accounting, Finance \& Management Discovery, 2(2), 71-94.

Osotimehin,K.O, Jegede, C.A, Akinlabi, B, H, \& Olajide, O.T (2012). An evaluation of the challenges and prospects of micro and small-scale enterprises development in Nigeria. American journal of contemporary research, .2, (4). 174-185

Otunaiya, A.O. Ambali, O.I. \& Idowu, A.O. (2013). Profitability and constraints analysis of women entrepreneurs in Lagos state, Nigerians/an journal of business management.5(l): 13-18.

Overseas Development Instimte, (1992). African development bank: facing new challenges, briefing papier, $21^{\text {st }}$ May 1992.

Owenvbiugie, R.O \& Igbinedion, V.I (2015) Role of finance on the growth of small and medium scale enterprises in Edo state of Nigeria. Journal of educational arid social research. Doi:10.5901/jesr. 2015.5(1),24 
Ranjith, J. G. \& Dayaratna-Banda, O. G (2014). Determinants of success of small business: a survey-based study in Kuliyapitiya divisional secretariat of Sri Lanka. International journal of business and social research (IJBSR).4(6),

Richard T. H \& Colin M. M (2007). Does Gender Matter? Women business angels and the supply of entrepreneurial finance, entrepreneurship theory and practice. Baylor University. 1042-2587

Sama'ila Idi N \& Tahir, H.M (2015). The role of bank of industry (BOI) in the development of small and medium scale enterprises (SMEs) in Bauchi Metropolis. Research Journal of Finance and Accounting. ISSN 2222-1697 (Paper) ISSN 2222-2847 (Online).

Sanusi, J. O. (2003). Overview of government's efforts in the development of SMES and the emergence of small and medium industries equity investment scheme (SMIEIS). A paper presented at the national summit on SMIEIS organized by the bankers' committee and Lagos chambers of commerce and industry (LCCI), Lagos, $10^{\text {th }}$ June. Retrieved fromwww.cenbank.org/out/speeches/2003/govadd-10bjune.pdf

Schumpeter, J. A. (1934). The theory of economic development. Cambridge, mass: Havard University Press.

Shahnawaz M.I.S: Corporate governance and business ethics for SMEs in developing countries: challenges and way forward.

Shaw, E. S. (1973). Financial deepening in economic development, oxford university Press, New York.

Taiwo, J.N, Falohun, T, O. \& Agwu M. E (2016). SMEs Financing and its effects on Nigerian economic growth. European journal of business, economics and accountancy. 4, (4), 2056-6018

Theamozhi. J. S \& Amaladas. L. A (2014). A Study on the role of financial institution in promoting entrepreneurship in small and medium enterprises with reference to Bangalore-European scientific journal,/special/edition. 1(1)1857-7881.

Usman M. A., Ahmed D. A., \& Yahaya H. G. (2015), The Role of government in financing small scale businesses in Maiduguri. Journal of business and management (IOSRJBM). 17(5),09-14. 
Vytautas, S. \& Vitalija, V. (2011). Hybrid venture capital hinds in Lithuania: motives, factors and present state of development, inzinerine ekonomika-engineering economics. 22(2) 157-164.

Wouter De M \& Tine C (2006). Small business financing: SMEs: FDT: internationalization financing constraints. Available at: http://ssrn.coin/abslTact=968 694. Retrieved from $1 / 12 / 2017$

Zacheus, O.O \& Adepoju, O.O (2014). The impact of small and medium scale enterprises on economic development of Ekiti State, Nigeria. Journal of economics and sustainable development. 5(16), 115-123. 